\title{
Exchange Rate Exposure and Firm Value: An Assessment of Domestic Versus Multinational Firms
}

\author{
Hajra Ihsan*, Abdul Rashid ${ }^{* *}$ and Anam Naz ${ }^{* * *}$
}

\begin{abstract}
This paper examines the impact of exchange rate changes on the stock returns of 232 nonfinancial firms listed on the Pakistan Stock Exchange, for the period January 2000 to June 2014. To mitigate the problem of heteroskedasticity, we use a generalized least squares estimator. The estimated regression models indicate that exchange rate variations have a significant effect on firm value and that firms are exposed significantly to one-period lagged variation in the exchange rate. Our results suggest that, in addition to exchange rate dynamics, increased exchange rate volatility appears to have significant and negative effects on firms' stock returns. Compared to domestic firms, multinational firms experience greater exchange rate exposure. Finally, we show that exchange rate depreciation and appreciation have significant differential effects on firms' stock returns. These effects vary significantly across domestic and multinational firms.
\end{abstract}

Keywords: Exchange rate exposure, stock returns, firm value, domestic firms, multinational firms, volatility of exchange rate, Pakistan.

\section{JEL classification: G32.}

\section{Introduction}

Since the breakdown of the Bretton Woods fixed exchange rate system in 1973, the influence of exchange rate levels and volatility on firm value has become increasingly important in international financial management (see Allayannis et al., 2001; Papaioannou, 2001, 2006; Jongen et al., 2012). According to standard economic theory, exchange rate volatility affects both the market value of firms as well as cash flows from their operations. The wide currency fluctuations observed over the last few

\footnotetext{
* Assistant Professor, Department of Economics, International Institute of Islamic Economics, International Islamic University, Islamabad, Pakistan.

** Associate Professor, Department of Economics, International Institute of Islamic Economics, International Islamic University, Islamabad, Pakistan.

*** MS Scholar, International Institute of Islamic Economics, International Islamic University, Islamabad, Pakistan.
} 
decades have reinforced the interest in empirically exploring the potential exposure of multinational and domestic firms to foreign exchange rates.

The literature examines several aspects of firms' exposure to exchange rate changes and the associated risks. Bartov and Bodnar (1994), Levi (1994) and Flota (2014) look at the exchange rate effect on firms' market value, while Baum et al. (2001) consider the impact on profitability. Bartram (2008) examines the effect on hedging activities and cash flows. Jorion (1991), Granger et al. (2000), Muhammad and Rasheed (2002), Rashid (2010), and Pan and Tang (2012) look at how exchange rate changes affect stock returns. Rashid and Khalid (2017) and Fidora et al. (2007) look at the impact on foreign portfolio investment (FPI). Finally, Nydahl (1999) and Rashid and Waqar (2017) gauge the effect on firms' internationalization and exporting decisions.

A common definition of exchange rate exposure is the sensitivity of firms' market value (stock returns) to unpredictable variations in exchange rates (Dumas, 1978; Adler \& Dumas, 1980; Hodder, 1982; Madura, 1989). Sensitivity to the exchange rate is defined as the possible direct loss (mainly due to unhedged exposure) or indirect loss in the firm's cash flows, assets, liabilities and net profit owing to exchange rate variations and, in turn, reductions in its stock market value (Papaioannou, 2006). Foreign exchange exposure is decomposed into the effect of exchange rate uncertainty on the value of net monetary assets with fixed nominal payoffs and the effect of exchange rate volatility on the value of real assets held by the firm.

Unlike domestic monetary assets, both short-term and long-term foreign monetary assets are exposed fully to exchange rate risks. In contrast, the value of real assets may be affected by exchange rate movements regardless of location (Levi, 1994). Thus, besides exchange rate effects on multinational firms, purely domestic firms such as utilities may also be affected by exchange rate movements through effects on aggregate demand or on the cost of traded inputs. Domestic firms that sell goods competing with imports will also be exposed to exchange rate movements (Jorion, 1990; de Jong et al., 2006). While any appreciation in the local currency would adversely affect the value of real assets for multinational firms that rely heavily on exports, it would benefit those multinationals (in terms of their foreign real assets) producing goods that are imported by the home country (Jorion, 1990). Managing exchange rate risk thus becomes a central part of decision making and activity for firms exposed to foreign currency risks (Allayannis et al., 2001). 
Hedging strategies to eliminate or at least reduce exchange rate exposure require understanding how, when and to what extent the volatility of the exchange rate affects firm operations, hedging techniques and the instruments available to deal with exchange rate exposure (Barton et al., 2002). For nonfinancial firms, managing exchange rate exposure is independent of their core business and generally handled by corporate treasuries, whereas multinational firms have risk committees to oversee the treasury's strategies for exchange rate exposure (Lam, 2003). This shows that foreign exchange exposure and its management are very important for both domestic and multinational firms.

There are three main types of exchange rate exposure: transaction exposure, translation exposure and economic exchange rate exposure (see Shapiro, 1996; Madura, 1989; Rashid, 2010). Transaction exposure involves cash flow risk and refers to the effect of exchange rate movements on transactional accounts related to receivables (export contracts), payables (import contracts) or repatriation of dividends (Papaioannou, 2006). Exchange rate variations in the currency of denomination of such contracts will result in direct transaction exchange rate exposure for firms.

Translation exposure is balance sheet exchange rate exposure, relating exchange rate movements to the valuation of a foreign subsidiary and, in turn, to its consolidation with the parent company's balance sheet (Shapiro, 1996; Madura, 1989). Translation exposure for a foreign subsidiary is generally measured by the exposure of net assets to expected exchange rate movements. In consolidating financial statements, the translation can be done either at the average exchange rate for that period or at the end-ofperiod exchange rate, depending on the accounting regulations affecting the parent company. Income statements are generally translated based on the average exchange rate for that period, but the balance sheet exposure of foreign subsidiaries is often translated at the prevailing current exchange rate at the time of consolidation (Papaioannou, 2006).

Economic exchange rate exposure refers to the sensitivity of a firm's present value of future operating cash flows to exchange rate variations. Economic exposure is related to the effect of exchange rate changes on operating expenses (cost of domestic inputs and imports) and revenues (domestic sales and exports). Economic exposure is usually applied to the present value of future cash flows from the operations of a firm's parent company and foreign subsidiaries. Thus, economic exchange rate exposure directly affects the firm's market value. Economic exchange rate exposure is long-lasting, with far-reaching effects on firms' 
value. Given this, one can define economic exposure as the effects of unexpected fluctuations in exchange rates on firms' market value. Put differently, a firm would be said to suffer from economic exchange rate exposure if its market value (share price) was significantly influenced by unpredictable variations in exchange rates.

This paper focuses on quantifying the economic exposure of exchange rate changes for a large sample of nonfinancial firms listed on the Pakistan Stock Exchange (PSE), by estimating the effect of exchange rate changes and volatility on their stock returns. Section 2 presents a literature review. Section 3 provides the study's methodology. Section 4 gives the variable definitions and data. Our empirical results are discussed in Section 4. Section 5 presents the study's conclusions.

\section{Literature Review}

The three approaches most commonly applied when exploring the relationship between exchange rates and stock returns are the traditional approach, portfolio approach and asset approach.

According to the traditional approach, exchange rate changes lead stock prices. For instance, currency depreciations increase the competitiveness of firms' exports, which, in turn, changes the value of their assets and liabilities, culminating in higher profits and hence higher stock prices - at least in the short run (Kutty, 2010). Solnik (1987), who originally proposed this channel, argues that real currency appreciation is bad news for a domestic corporation because it reduces its competitive ability to export. On the other hand, a real depreciation improves domestic firms' ability to export in the short run.

The portfolio approach asserts that exchange rates are determined by a market mechanism and, therefore, stock prices are expected to lead the exchange rate with a negative correlation. This is because a reduction in stock prices reduces domestic wealth, which lowers the demand for money and, in turn, interest rates. A decrease in domestic stock prices also reduces foreign investors' demand for domestic real assets and domestic currency. Such changes in currency demand and supply result in capital outflows and depreciation of the domestic currency (Granger et al., 2000; Caporale et al., 2002; Stavárek, 2005; Pan et al., 2007; Aydemir \& Demirhan, 2009; Kutty, 2010).

Finally, under the asset approach, the current money price of any asset is equivalent to its discounted future money prices. This approach 
considers the exchange rate to be the price of an asset, that is, the price of one unit of foreign currency in domestic currency. Like the prices of other assets, exchange rates are derived from expected future exchange rates. Any news or factor that affects the future value of the exchange rate will also affect today's exchange rate. Such news or factors may be different from those that influence stock prices. In such a scenario, there would be no relationship between exchange rates and stock prices (Muhammad \& Rasheed, 2002). Different approaches predict different relationships between exchange rates and stock prices.

In addition to these three approaches, the literature offers other explanations for firms' exchange rate exposure and their market values. If investors in stock markets are either risk-neutral or risk-seeking, then the exchange rate risk may be viewed as an additional chance to earn higher stock returns. This could increase the demand for stocks that are more exposed to exchange rate risk. On the other hand, risk-averse investors will consider the exchange rate risk an extra cost and thereby invest less in stocks of firms that are more exposed to exchange rate variations. In this context, the effect of exchange rate exposure on the value of firms is conditional on the attitude of investors toward risk. Therefore, we argue that the theoretical literature does not necessarily offer a consensus on the nature of the relationship between exchange rates and stock prices, implying that the effect of exchange rates and exchange rate volatility on stock returns is an empirical issue.

On reviewing the empirical literature, we find that firms' exposure to foreign exchange rates has been studied extensively in the context of developed countries. For example, Choi and Prasad (1995) examine the effect of exchange rates on US firms, He and $\mathrm{Ng}$ (1998) study exchange rate effects for Japanese firms, and Al-Shboul and Anwar (2014) provide evidence for Canadian firms. These empirical studies mostly find significant exposure in the case of multinational and domestic firms.

Empirical studies also provide conflicting evidence of the association between exchange rates and firm value (stock prices). For example, Jorion (1990, 1991), Bartov and Bodnar (1994), Choi and Prasad (1995), Allayannis (1996) and Doidge et al. (2000) report no significant association between exchange rate changes and firm value. However, other studies present evidence that the exchange rate has a significant and strong influence on firms' market value and stability (see, for instance, Hodder, 1982; Miller \& Reuer, 1998; Bodnar \& Wong, 1999; Marston, 2001; Pritamani et al., 2004). Similarly, Baum et al. (2001) show that a decline in the domestic currency value decreases firm profits. 
In a recent study, Rashid and Waqar (2017) use a sample of Pakistani nonfinancial firms to show that real exchange rate changes are positively related to firms' export performance, whereas real exchange rate volatility is negatively related to their export performance. Analogously, Rashid and Khalid (2017) investigate the sensitivity of FPI to exchange rate risk and find that exchange rate changes and volatility both have negative, significant and long-lasting effects on FPI in Pakistan.

The theoretical rationale above indicates that domestic companies that are not engaged in international sales may also be affected by exchange rate instability due to competition with other companies (Jorion, 1990; de Jong et al., 2006). Empirically, there is mixed evidence of the impact of exchange rate risk on domestic firms. For example, Jeddi (2001) reports that domestic firms are not exposed to exchange rate changes to any considerable degree. There is also evidence that exchange rate exposure has greater influence on multinational firms' profitability compared to their domestic counterparts (Doukas et al., 2003). On the other hand, Aggarwal and Harper (2010) show that domestic firms' value as well as profitability is significantly exposed to exchange rates and that the effect of exchange rate volatility on domestic firms is not much different from the exchange rate effect on multinational firms.

However, the literature on the effect of exchange rates on firms' value in developing countries is relatively limited (Rashid, 2010). Exchange rate variations are generally more visible in highly inflationary developing economies. For instance, during 1991-98, Turkey experienced high inflation and rapid currency depreciation. For this period, Kiymaz (2003) compares the variance in exchange rate movements of the Turkish lira in terms of other currencies (such as the US dollar, pound sterling, French franc, and German mark) and the variation in foreign currencies in terms of other foreign currencies. His analysis indicates that exchange rates involving the Turkish lira were the most volatile.

Like other developing countries, Pakistan has experienced a series of high-inflation and quick-currency-depreciation episodes over the last few decades. The energy crisis, political instability and disparities in the balanceof-payment accounts have also contributed significantly to rapid fluctuations in the exchange rate. Further, like other developing and emerging economies, firms operating in Pakistan might not actively hedge their exchange rate exposure. Given this background, the economic exchange rate exposure of Pakistani firms is worth exploring, both from a policy point of view as well as from the perspective of investors and firm managers. 
Many studies have looked at the impact of exchange rates on different variables in Pakistan, focusing particularly on exchange rate determinants, exchange rate stability and its relationship with different variables such as trade, interest rates, the rate of inflation, exports, FPI and financial derivatives. ${ }^{1}$ We depart from such studies in that we examine the economic exchange rate exposure of nonfinancial Pakistani firms.

In principle, we would expect firms to be more exposed to exchange rate risks in a weak currency environment, such as that prevailing in Pakistan. In general, a modest decline in the local currency benefits firms operating in that country, but when the decline is severe or protracted, several challenges arise for such firms (J.P. Morgan, 2017). A severe depreciation is typically a sign of weak economic fundamentals and is generally associated with falling economic growth. Due to expensive imports, a weaker currency may lead to inflationary pressure in the economy. To protect the currency, the government generally raises interest rates and may introduce other regulatory measures and capital controls. Decreases in the interest rate may further slow the process of growth and capital controls can increase risk for both domestic and multinational corporations (MNCs). Domestic firms with liabilities in strong currencies but cash flows in their home currency are typically under more pressure and may reduce their investments.

This paper provides an opportunity to observe whether the effects of exchange rate changes on firm value are consistent with developed economies. We also examine whether domestic firms and MNCs respond differently to exchange rate changes, and if exchange rate appreciations and depreciations have different effects on firms' stock returns. To carry out the empirical analysis, we use an unbalanced panel dataset for a large sample of nonfinancial firms listed on the PSE over the period January 2000 to June 2014. To mitigate the problem of heteroskedasticity, we use a generalized least squares (GLS) estimator.

The paper is motivated by the deficiency of the literature pertaining to Pakistan on the effect of exchange rate changes on firm value, and the importance of this topic in the international financial literature in general and - given its weak currency environment - for Pakistan in particular. Rashid (2010) is an exception in that he examines economic exchange rate exposure in Pakistan using industry-level stock returns and covering all

\footnotetext{
${ }^{1}$ See Rashid and Khalid (2017), Rashid and Waqar (2017), Rashid (2013), Kemal (2005), Afza and Alam (2011), and Khan and Qayyum (2007).
} 
types of industries (22 in all) instead of focusing on export-oriented or/and import-oriented industries, over the period June 1991 to December 2007. His findings indicate significant exposure to exchange rates for Pakistani industries.

This paper differs from Rashid (2010) in several ways. First, we use firm-level data. Second, we examine the effects of exchange rate volatility over and above the effects of exchange rate changes, whereas Rashid focuses on the effects of exchange rate fluctuations. Third, we examine the effects of exchange rate changes and volatility on the market value of both domestic firms and MNCs. Finally, and more important, we explore the differential effects of exchange rate appreciations and depreciations on firms' stock returns. Our study also differs considerably from Jorion (1990). We analyze the exchange rate exposure of nonfinancial firms listed on the PSE, while Jorion looks at US multinationals in this context. Moreover, unlike Jorion, we assess the difference in exchange rate exposure across domestic and multinational firms, and examine how the differential effects of appreciations and depreciations vary across domestic firms and MNCs.

Thus far, the literature has not analyzed the effects of exchange rate changes on the value of Pakistani nonfinancial firms. There is also a lack of empirical evidence on whether domestic and multinational firms respond differently to exchange rate variations. Examining the exchange rate exposure of domestic and multinational firms in a relatively weak currency environment such as Pakistan would increase our understanding of the effects of exchange rates on firm value. In this context, our study helps extend the literature.

Our findings could help firm managers design an appropriate strategy for hedging exposure to exchange rates. There are several risk management theories that analyze the effect of risk-hedging decisions on firm value. For instance, Smith and Stulz (1985) and Leland (1998) assess the effect of hedging on debt capacity, while Allayannis and Weston (2001) and Carter et al. (2006) investigate its effect on value. Froot et al. (1993) study the effect of hedging on investment policies. They argue that, due to capital market imperfections, the use of derivatives for risk management strategies can affect firm value - for instance, by reducing expected taxes and financial distress costs, mitigating underinvestment and increasing debt capacity to take advantage of debt tax shields. 


\section{Methodology}

To examine the relationship between firm value and exposure to exchange rates, we select the commonly used two-factor model specified by Jorion (1990), modified to accommodate issues related to the relationship between firm value and exchange rates. We begin by estimating Jorion's model and comparing our results with those obtained by other studies that have also estimated this model. The model is defined as follows:

$$
R_{i t}=\beta_{c}+\beta_{x} E X_{t}+\beta_{m} R_{m, t}+\varepsilon_{i, t}
$$

where $R_{i t}$ is the stock return of firm $i$ at time $t, E X_{t}$ is the percentage change in the exchange rate variable in month $t$ (the orthogonalized exchange rate change), $R_{m, t}$ is the market return at the end of $t, \beta_{c}$ is the constant term, $\beta_{x}$ measures firm-level exchange rate sensitivity in excess of the market's exchange rate reaction, $\beta_{m}$ is the beta with respect to market returns, and $\varepsilon_{i, t}$ is the error term with a zero mean and constant variance.

In equation (1), the exposure coefficient $\left(\beta_{x}\right)$ measures the exposure to exchange rate elasticity as the difference between firms' total exposure elasticity and the market's exposure elasticity adjusted by the firms' market beta. Thus, we refer to $\beta_{x}$ as the residual exposure elasticity of the firm. Incorporating market returns into the model controls not only for the effect of macroeconomic factors, but also for the market portfolio's own exposure to exchange rates. ${ }^{2}$

Bartov and Bodnar (1994) argue that investors find it difficult to understand the complex relationship between exchange rate variations and firm value. As a result, mispricing may arise in the market, which then affects stock returns. Since investors discover the impact on firm value gradually after new information is released, the exchange rate can affect stock prices with a lag rather than contemporaneously. Bartov and Bodnar refer to this lagged stock price response as the 'delayed-response hypothesis.' They explain this as the inability of financial analysts and equity markets to adequately and precisely forecast the effects of exchange rate changes on firms' earnings during the current period. This, in turn, accounts for the delayed response of stock prices to exchange rate exposure.

\footnotetext{
${ }^{2}$ Macroeconomic variables - such as the change in the risk-free rate, the market risk premium and investor sentiment that happens to be correlated with the exchange rate - affect the valuation of all firms. To control for macroeconomic influences on realized returns, we include market portfolio returns in the model proposed by Jorion (1990).
} 
The lagged effect suggests that it takes time for the impact of exchange rate changes to be reflected in stock prices, implying market inefficiency. To this 'delayed-response hypothesis' and in line with other studies such as Doukas et al. (2003), de Jong et al. (2006), Rashid (2010), and Rashid and Khalid (2017), we include the one-month and two-month lagged values of the exchange rate: ${ }^{3}$

$$
R_{i, t}=\beta_{c}+\beta_{x} E X_{t}+\beta_{x 1} E X_{(t-1)}+\beta_{x 2} E X_{(t-2)}+\beta_{m} R_{m, t}+\varepsilon_{i, t}
$$

Economic agents are also very interested in exchange rate volatility, which affects not only a given economy, but also the economies of other countries. Policymakers use information on how exchange rate volatility influences different macroeconomic variables. Firm managers consider exchange rate volatility in different models to measure the risk they face. This study also determines how the volatility of the exchange rate (ver) affects firm value:

$$
\begin{aligned}
R_{i, t}= & \beta_{c}+\beta_{x} E X_{t}+\beta_{x 1} E X_{(t-1)}+\beta_{x 2} E X_{(t-2)}+ \\
& \beta_{m} R_{m, t}+\beta_{v e r} \operatorname{ver}\left(\sigma_{t}^{2}\right)+\varepsilon_{i, t}
\end{aligned}
$$

In principle, both firm managers and investors view positive and negative changes in exchange rates differently. Proponents of behavioral finance suggest that investors behave differently in case of favorable and unfavorable effects of any event. While investors generally want 'downside protection' from adverse effects, they might also be keen to avail the 'upside potential' to maximize their benefits. This makes it worth exploring whether stock prices respond differently to exchange rate appreciation and depreciation.

To examine the differential impact of exchange rate depreciation and appreciation, we classify exchange rate changes by creating two dummy variables. The dummy for exchange rate appreciation $\left(D_{t}^{a p p}\right)$ takes a value of 1 when the exchange rate change is positive and 0 otherwise. The dummy for exchange rate depreciation $\left(D_{t}^{d e p}\right)$ takes a value of 1 when the exchange rate change is negative and 0 otherwise. We then multiply both dummies by the orthogonal exchange rate changes to gauge the differential effect of appreciation and depreciation:

\footnotetext{
${ }^{3}$ Our choice of a lag length of 2 is based on the literature. However, we also assume that, since investors trade frequently both in the forex and stock exchange markets, the two-month period is enough for stock prices to fully reflect exchange rate information.
} 


$$
\begin{aligned}
R_{i, t}= & \beta_{c}+\beta_{x}^{+} E X_{t} \times D_{t}^{a p p}+\beta_{x 1}^{+} E X_{(t-1)} \times D_{(t-1)}^{a p p}+\beta_{x 2}^{+} E X_{(t-2)} \times \\
& D_{(t-2)}^{a p p}+\beta_{x}^{-} E X_{t} \times D_{t}^{d e p}+\beta_{x 1}^{-} E X_{(t-1)} \times D_{(t-1)}^{d e p}+\beta_{x 2}^{-} E X_{(t-2)} \times \\
& D_{(t-2)}^{d e p}+\beta_{m} R_{m, t}+\beta_{v e r} \operatorname{ver}\left(\sigma_{t}^{2}\right)+\varepsilon_{i, t}
\end{aligned}
$$

To analyze the effect of exchange rate changes on stock returns, one could use ordinary least squares to estimate the above models for each firm separately. However, the existence of heteroskedasticity - a common feature of monthly and weekly financial time series - impairs the reliability of these estimates. To mitigate the problem of heteroskedasticity, we apply a GLS estimator and run a panel regression.

While numerous studies have debated the appropriate method to measure exchange rate volatility, the literature does not provide any consensus on adopting a generally accepted method. The most commonly used model is the autoregressive conditional heteroskedasticity $(\mathrm{ARCH} / \mathrm{GARCH})$ approach. Both the $\mathrm{ARCH}$ and GARCH models are used especially to analyze stock prices, inflation rates and exchange rates. A distinguishing feature of these models is that the error variance may be correlated over time, given the phenomenon of volatility clustering. We measure exchange rate volatility by estimating a GARCH model.

\section{Data and Variables}

Our paper uses monthly data spanning January 2000 to June 2014. We obtain the daily stock price data for nonfinancial firms listed on the PSE and use this to calculate their monthly stock returns. We consider those firms for which at least 10 years' continuous stock price data is available, ${ }^{4}$ which yields a sample of 232 nonfinancial firms. The monthly market index data is also taken from the PSE and the monthly exchange rate data in terms of Pakistani rupees per US dollar is obtained from the State Bank of Pakistan's Statistical Bulletin (2016 and earlier). Using monthly data to carry out the empirical analysis will yield more robust estimates of economic exchange rate exposure, since both exchange rates and stock prices are high-frequency time series.

\footnotetext{
${ }^{4}$ We apply this criterion to obtain robust estimates of economic exchange rate exposure. Considering only those firms for which 10 years' stock price data is available allows us to examine the exchange rate exposure of relatively mature firms and for those that have had time to diversify their sales and other economic activities. This restriction does not create the problem of survival bias in our sample since we allow the entry and exit of firms for which more than 10 years' data is available.
} 
To study the exchange rate exposure of both types of firms, we split our sample into domestic and multinational firms, following Jorion (1990), Doukas et al. (2003) and others. Using the foreign sales ratio (foreign sales/total sales) to identify multinational firms, we consider a firm an MNC if its foreign sales ratio is greater than 10 percent. This criterion splits our sample of 232 firms into 117 multinational firms and 105 domestic firms. Ten firms are dropped from the sample due to insufficient information on their foreign sales. The variables used in the regression are stock prices, the orthogonalized exchange rate, the market index and exchange rate volatility (Table 1).

Table 1: Description of variables

\begin{tabular}{|c|c|c|}
\hline Variable & Notation & Description \\
\hline Stock returns & $R_{i, t}$ & $\begin{array}{l}\text { Return of firm } i \text { for period } t \text {, defined as } R_{i, t}=\ln \left(P_{i t} /\right. \\
\left.P_{i(t-1)}\right) \text {, where } P_{t} \text { and } P_{t-1} \text { are the current and one- } \\
\text { period lag stock prices of the } i \text { th firm. }\end{array}$ \\
\hline $\begin{array}{l}\text { Percentage change in } \\
\text { exchange rate }\end{array}$ & $E X_{t}$ & $\begin{array}{l}\text { Percentage (orthogonalized) change in the exchange rate } \\
\text { in month } t \text {. }\end{array}$ \\
\hline Market return & $R_{m, t}$ & $\begin{array}{l}\text { The log of the monthly KSE } 100 \text { index is used to } \\
\text { calculate monthly stock market returns. }\end{array}$ \\
\hline $\begin{array}{l}\text { Exchange rate } \\
\text { volatility }\end{array}$ & $\operatorname{ver}\left(\sigma_{t}^{2}\right)$ & Calculated using a GARCH model. \\
\hline
\end{tabular}

Note: Market and exchange rate risk factors may be correlated with, or influenced jointly by, certain external shocks. To avoid any bias due to factor correlations, we orthogonalize the exchange rate risk factor and regress exchange rate changes on the market factor to obtain orthogonal residuals and use them in our models.

The selection criterion leads to GARCH $(1,1)$ from which the GARCH variances are extracted.

\section{Empirical Results}

This section presents the study's results. We start with an analysis of all firms followed by analysis of domestic and foreign firms.

\subsection{Exchange Rate Exposure for All Firms}

The results for exchange rate exposure and stock prices are summarized in Table 2. Using the change in the orthogonalized exchange rate as the independent explanatory variable in Model 1, we find that, overall, nonfinancial firms are negatively affected by exchange rate changes, but to a statistically insignificant degree. This indicates either that the stock prices of Pakistani firms are not sensitive to contemporaneous orthogonalized exchange rate changes or that nonfinancial firms have the same exchange rate exposure as the market portfolio. However, when we 
add two-month lagged responses to orthogonalized exchange rate changes in Model 2, the negative coefficient on exchange rate changes increases in magnitude and becomes statistically significant. This negative exposure effect implies that a depreciation (appreciation) in the Pakistani rupee decreases (increases) firm value.

Our results indicate that lagged exchange rate changes are statistically significant when applying a one-month lag, but statistically insignificant in the case of a two-month lag. This lagged response could reflect the difficulty investors face in understanding the complex relationship between exchange rate variations and firm value (Bartov \& Bodnar, 1994). These lagged responses indicate that it takes time for the impact of exchange rate changes to be reflected fully in stock prices, suggesting that the equity market is inefficient when it comes to incorporating all the available information instantly (de Jong et al., 2006). A possible explanation for the positive one-period lagged effect of the exchange rate on firm value is that firms may need time to design strategies to minimize exchange rate exposure and to reap the advantages of a depreciation of the home currency (increased exchange rate).

Table 2: Exchange rate exposure for all firms

\begin{tabular}{lccc}
\hline Coefficient & Model 1 & Model 2 & Model 3 \\
\hline$\beta_{x}$ & -0.0001 & -0.0023 & -0.0021 \\
& $(0.915)$ & $(0.003)$ & $(0.005)$ \\
$\beta_{x 1}$ & & 0.0037 & 0.0037 \\
& & $(0.000)$ & $(0.000)$ \\
$\beta_{x 2}$ & & 0.0005 & 0.0047 \\
& & $(0.477)$ & $(0.553)$ \\
$\beta_{m}$ & 0.3768 & 0.3692 & 0.3642 \\
& $(0.000)$ & $(0.000)$ & $(0.000)$ \\
$\beta_{\text {ver }}$ & & & -0.0008 \\
& & & $(0.005)$ \\
$\beta_{c}$ & 0.0012 & 0.0033 & -0.008 \\
& $(0.08)$ & $(0.000)$ & $(0.060)$ \\
Number of firms & 232 & 232 & 232 \\
\hline
\end{tabular}

Note: Values given in parentheses are p-values.

Source: Authors' calculations.

The estimates yielded by Model 3 show that the exposure coefficient on orthogonalized changes in the exchange rate is negative and statistically significant, and that the one-month lagged response and exchange rate volatility are also statistically significant. Taken together, our results indicate 
that the current level of the exchange rate significantly and negatively affects nonfinancial firms in Pakistan. However, the one-period lagged exchange rate has a positive and significant effect on firms' market value.

The significance of exchange rate exposure for firm value is consistent with Doukas et al. (1999) for Japanese firms, Kiymaz (2003) for Turkish firms and Rashid (2010) for firms in Pakistan. There are several explanations for the significant effect of exchange rate changes on firm value. First, Pakistan is a small open economy and highly integrated, economically and financially, with other emerging and developed economies. Second, firms operating in Pakistan not only export their products, but also use several imported inputs in production. This implies that changes in the exchange rate would affect them significantly through the impact on operating expenses (the cost of domestic inputs and imports) and revenues (domestic sales and exports). Third, firms might not be actively adopting hedging strategies to counter their exposure to exchange rates, at least during the current month, for the effect of exchange rate changes to become apparent.

\subsection{Exchange Rate Exposure for Domestic Firms}

The monthly stock returns of 105 domestic firms for the period January 2000 to June 2014 are regressed jointly on exchange rate changes, lagged exchange rate changes, exchange rate volatility and the market index for Models 1,2 and 3. The results are given in Table 3.

Table 3: Exchange rate exposure for domestic firms

\begin{tabular}{lccc}
\hline Coefficient & Model 1 & Model 2 & Model 3 \\
\hline$\beta_{x}$ & -0.0014 & -0.010 & -0.008 \\
& $(0.435)$ & $(0.000)$ & $(0.001)$ \\
$\beta_{x 1}$ & & 0.0097 & 0.014 \\
& & $(0.000)$ & $(0.000)$ \\
$\beta_{x 2}$ & & -0.0042 & -0.0024 \\
$\beta_{m}$ & & $(0.085)$ & $(0.314)$ \\
& & 0.3169 & 0.3197 \\
$\beta_{\text {ver }}$ & 0.2970 & $(0.000)$ & $(0.000)$ \\
$\beta_{c}$ & $(0.000)$ & & -0.0129 \\
& & & $(0.000)$ \\
Number of firms & -0.0004 & -0.0003 & -0.1733 \\
& $(0.855)$ & $(0.920)$ & $(0.000)$ \\
\hline
\end{tabular}

Note: Values given in parentheses are p-values.

Source: Authors' calculations. 
The results of the regression for domestic firms indicate that firms experience a statistically insignificant negative impact of exposure to exchange rates in Model 1. In Model 2, which incorporates lagged exchange rate changes, domestic firms have a significant contemporaneous and onemonth lagged response, but an insignificant two-month lagged response.

The exposure coefficients in Model 3 reveal a negative and statistically significant impact of contemporaneous exchange rate exposure. The negative relationship between exchange rate changes and firm value implies that a depreciation of the Pakistani rupee against the US dollar leads to a decline in the market value of domestic firms. Further, the estimates indicate that domestic firms experience a significant one-month lagged impact of exposure to the exchange rate. However, this effect appears to be positive. Pakistan's financial markets are not efficient enough to instantly and fully incorporate information on the exchange rate into their stock prices. We also find that exchange rate volatility has a significant, negative effect on the market value of domestic firms. This implies that unexpected exchange rate variations negatively affect domestic firms' operations.

Overall, the results point to a significant association between exchange rate variations and the value of domestic firms. Our results are consistent with those of several other studies - including Aggarwal and Harper (2010) for US firms, Pan and Tang (2012) for Chinese firms, and Alssayah and Krishnamurti (2013) for UAE firms - which find that, as with MNCs, domestic firms are impacted significantly by exposure to exchange rate changes.

The significant exchange rate exposure impacts we present in this study may be a result of the effect of exchange rate variations on net real assets. As mentioned in the introduction, the value of real assets is affected significantly by exchange rate movements and these effects will hold whatever their location (Levi, 1994). Thus, even purely domestic firms may be affected by exchange rate movements through the exchange rate exposure effect on aggregate demand or on the cost of traded inputs. Domestic firms that sell goods competing with imports will also be exposed to exchange rate movements (Jorion, 1990; de Jong et al., 2006).

\subsection{Exchange Rate Exposure for MNCs}

The monthly stock returns of 117 multinational firms for the period January 2000 to June 2014 are regressed jointly on exchange rate changes, lagged exchange rate changes, exchange rate volatility and the market index 
for Models 1, 2 and 3. The results are summarized in Table 4. The results show that multinational firms experience negative and statistically significant impacts of exposure to the exchange rate in all three models. The negative contemporaneous exposure coefficient means that any depreciation of the Pakistani rupee against foreign currency has an adverse effect on the value of multinational firms. The one-period lagged exchange rate change is positively and significantly correlated to firm value, whereas the second-period lagged exchange rate change is negatively and significantly correlated with firm value for MNCs.

As explained above, firms may need time to reap the benefits of a local currency depreciation. However, an ongoing depreciation will adversely affect their activities and, in turn, negatively affect their market value. Another possible explanation for the negative effect of second-period lagged exchange rate changes is that a continuous decrease in the value of currency may adversely affect investors' confidence: if the demand for MNC shares falls, this will have a negative effect on firms' market value. Our findings on the lagged response to exchange rate exposure support Bartov and Bodnar (1994), but are in contrast to the findings of He and $\mathrm{Ng}$ (1998) and Nydahl (1999).

Table 4: Exchange rate exposure for MNCs

\begin{tabular}{lccc}
\hline Coefficient & Model 1 & Model 2 & Model 3 \\
\hline$\beta_{x}$ & -0.0043 & -0.0082 & -0.0075 \\
& $(0.013)$ & $(0.000)$ & $(0.000)$ \\
$\beta_{x 1}$ & & 0.0156 & 0.017 \\
& & $(0.000)$ & $(0.000)$ \\
$\beta_{x 2}$ & & -0.0100 & -0.0096 \\
& & $(0.000)$ & $(0.000)$ \\
$\beta_{m}$ & 0.3124 & 0.3696 & 0.370 \\
$\beta_{v e r}$ & $(0.000)$ & $(0.000)$ & $(0.000)$ \\
& & & -0.0037 \\
$\beta_{c}$ & & & $(0.053)$ \\
& 0.0004 & 0.0025 & -0.047 \\
Number of firms & $(0.768)$ & $(0.071)$ & $(0.06)$ \\
\hline
\end{tabular}

Note: Values given in parentheses are p-values.

Source: Authors' calculations.

In Model 3, the exchange rate volatility variable appears to be significant and negative. This implies that exchange rate volatility has a deteriorating effect on the market value of multinationals - a finding 
consistent with that for domestic firms. This suggests that, regardless of whether a firm is domestic or multinational, its value is affected negatively by exchange rate volatility.

Overall, our results for the significant effect of exchange rate variations on the value of multinational firms are consistent with Dominguez and Tesar (2006) and Faff and Marshall (2005). Both studies investigate the effect of exchange rates on multinational firm value for developed and emerging economies (the UK, Canada, Japan and Germany) and obtain significant results. However, our findings contradict Al-Shboul and Anwar (2014) and Bhuiya et al. (2015), who obtain weak results for the exchange rate exposure of Canadian and British multinational firms, respectively. A possible reason for MNCs' significant exposure to exchange rate changes is that they are actively involved in international transactions and might not use foreign currency derivatives extensively to hedge against exchange rate movements.

In sum, the results given in Tables 3 and 4 suggest that the contemporaneous as well as two-month lagged impact of exchange rate changes on the market value of both domestic and multinational firms is significant and negative. Moreover, the two-month lagged response of firms is stronger than the contemporaneous response, while the lagged effect of exchange rate changes is larger for MNCs. In contrast, the onemonth lagged response of firm value to exchange rates is, surprisingly, positive and significant.

These findings have several important implications. The significant, lagged firm value response strongly supports the 'delayed response hypothesis' proposed by Bartov and Bodnar (1994). According to this hypothesis, financial experts and investors may be unable to adequately and precisely foresee the effects of exchange rate changes on firms' earnings during the current period. Rather, they discover the impact of exchange rate changes on firms' operations gradually. This inability to effectively and accurately forecast the impact of exchange rates on firms' cash flow streams in the current period could explain the delayed response of stock prices to exchange rate exposure. The findings also suggest that stock prices in Pakistan take time to fully reflect the negative effects of exchange rate exposure.

We offer three alternative explanations for the larger impact of the two-month lagged exchange rate change relative to the contemporaneous exchange rate change. The first is related to forecasting ability: even though 
investors and financial specialists might forecast the exchange rate effect on firms' earnings in anticipation of exchange rate changes, they are in a better position to update and modify these forecasts given the realized response to exchange rate changes. The second explanation is that, while financial investors might accurately predict the effect of exchange rate changes before they occur, they still need time to divert their portfolio allocation away from stocks that are highly exposed to exchange rate risk. The third explanation is based on the market efficiency hypothesis. Pakistan's equity market is not efficient enough to fully and instantly incorporate all information on exchange rate movements. This inefficiency results in the delayed response of stock prices to exchange rate changes.

The positive relationship between firm value and the one-period lagged exchange rate is somewhat surprising and adds to the puzzle: why do firms sometimes experience positive impacts of exchange rate changes? A possible explanation is that both domestic firms and MNCs may take time to design strategies to minimize their exchange rate exposure and take advantage of a home currency depreciation (increased exchange rate). Financial hedges, currency netting, finding new foreign markets in which to sell outputs and sourcing factor inputs overseas all require time. It is also possible that firms might sign contracts in advance and in anticipation of exchange rate movements to mitigate adverse exchange rate effects and to take advantage of favorable exchange rate movements. The impact of exchange rate exposure on firm value may vary over time because of these contracts.

Our evidence on the time-varying response of stock prices to exchange rate changes suggests that exchange rate movements discourage investors in the current period. In the following period, they may hedge exchange rate risk using suitable hedging strategies and invest more in exchange rate risk-exposed stocks, perhaps to obtain higher exchange rate risk premiums. However, since they may choose not to bear hedging costs for longer periods and since continuous exchange rate movements give investors a negative signal, they may sell the stocks of firms facing exchange rate exposure. Although we are unable to offer any adequate explanation for the positive impact of the two-month lagged exchange rate, we propose a framework to examine the contemporaneous and lagged firm value response conditional on the direction of exchange rate changes. 


\subsection{Differential Exchange Rate Exposure}

Having established the effects of exchange rate changes on both domestic and multinational firms, we present another set of results to examine the differential impact of exchange rate depreciations and appreciations. We classify exchange rate changes by creating two dummy variables. The dummy for exchange rate appreciations takes a value of 1 when the exchange rate change is positive and 0 otherwise. The dummy for exchange rate depreciations takes a value of 1 when the exchange rate change is negative and 0 otherwise. We then multiply both dummies by the orthogonal exchange rate changes to obtain the differential effect of exchange rate appreciations and depreciations for the whole sample as well as for multinational and domestic firms. The results of the fixed effects model are presented in Table 5. We estimate three models: Model 1 for all firms, Model 2 for domestic firms and Model 3 for multinational firms.

The estimates indicate that exchange rate appreciations and depreciations affect stock returns differently. For example, firms are negatively affected when exposed to current exchange rate appreciations, whereas exchange rate depreciations have a significant positive effect on stock returns. Similarly, a one-period lagged exchange rate appreciation has a positive impact, whereas a one-period lagged exchange rate depreciation has a significant and negative impact on stock returns. Finally, we find that a two-month lagged exchange rate appreciation does not have any statistically significant impact on firm value. However, a two-month lagged exchange rate depreciation is negatively related to stock returns. These findings suggest that current and lagged exchange rate appreciations and depreciations have different effects on firms' stock returns.

The effect of exchange rate appreciations and depreciations also differs across domestic and multinational firms. For instance, although both domestic and multinational firms are negatively affected by current exchange rate appreciations, this effect is statistically insignificant in the MNC case. Similarly, a two-month lagged exchange rate appreciation has a negative effect on MNC stock returns, but we find no such effect for domestic firms. Interestingly, both types of firms are positively and significantly affected by a one-month lagged exchange rate appreciation. 
Table 5: Exchange rate depreciation versus appreciation exposure

\begin{tabular}{lccc}
\hline Coefficient & All firms & Domestic firms & Multinational firms \\
\hline$\beta_{x}^{+}$ & -0.012 & -0.012 & -0.002 \\
& $(0.000)$ & $(0.000)$ & $(0.387)$ \\
$\beta_{x 1}^{+}$ & 0.031 & 0.016 & 0.016 \\
& $(0.000)$ & $(0.000)$ & $(0.000)$ \\
$\beta_{x 2}^{+}$ & 0.002 & 0.001 & -0.007 \\
& $(0.475)$ & $(0.987)$ & $(0.002)$ \\
$\beta_{x}^{-}$ & 0.007 & 0.004 & -0.019 \\
& $(0.000)$ & $(0.354)$ & $(0.000)$ \\
$\beta_{x 1}^{-}$ & -0.019 & -0.007 & 0.006 \\
& $(0.000)$ & $(0.229)$ & $(0.119)$ \\
$\beta_{x 2}^{-}$ & -0.002 & -0.006 & -0.018 \\
& $(0.074)$ & $(0.113)$ & $(0.000)$ \\
$\beta_{m}$ & 0.361 & 0.306 & 0.358 \\
& $(0.000)$ & $(0.000)$ & $(0.000)$ \\
$\beta_{v e r}$ & -0.235 & -0.164 & -0.633 \\
$\beta_{c}$ & $(0.000)$ & $(0.000)$ & $(0.100)$ \\
& 0.005 & 0.007 & -0.002 \\
Number of firms & $(0.000)$ & $(0.002)$ & $(0.318)$ \\
\hline
\end{tabular}

Source: Authors' calculations.

The results given in the table also show that the effects of exchange rate depreciations differ significantly between domestic and multinational firms. Specifically, we find that exchange rate depreciations do not have a significant effect on the stock returns of domestic firms. In contrast, MNC stock returns are affected significantly and negatively by exchange rate depreciations.

\section{Conclusion}

Exchange rate variations can have a significant effect on firms' market value by affecting their cash flows, assets and liabilities. In this study, we have analyzed 232 firms listed on the PSE for the period January 2000 to June 2014. The results of the all-firms regression suggest negative and significant effects of exchange rate exposure. Specifically, we find that exchange rate changes have a negative and statistically significant effect on the market value of firms. The results also show that the volatility of the exchange rate has a significant and negative effect on firms' market value. 
Having examined the exchange rate exposure effects of the whole sample, we separate domestic and multinational firms to establish whether this exposure differs across the two types of firms. Analyzing a sample of 105 domestic firms yields negative and significant exposure coefficients. We also find that the one-month lagged response to exchange rate changes is significant for domestic firms. The effect of exchange rate exposure in this case could be explained as follows: product prices are effectively determined by market forces and the impact of exchange rate fluctuations is reflected in a firm's stock prices and ultimately in its value or profitability.

Next, we analyze the exchange rate exposure of 117 multinational firms, where exchange rate changes have a significant and negative effect on their market value. We also gauge their one-month and two-month lagged responses to exchange rate changes. Our results suggest that the market value of both types of firms is significantly and negatively affected by exchange rate volatility. These findings imply that the exchange rate volatility variable is an important empirical determinant of firm value, regardless of whether the firm is domestic or multinational.

The lagged response of multinational firms to exchange rate changes is stronger than that of domestic firms. One possible reason for this relatively strong effect is that multinationals are more involved in internationalization and exporting activities, which means that their operations and other activities are more exposed to unexpected fluctuations in exchange rates. Our findings suggest that such firms must employ effective and active hedging strategies against changes in exchange rates to maintain their profits and value. Moreover, the government should design policies that help stabilize exchange rates, in turn, enhancing the market value of firms. There is also a need to provide an environment that not only helps, but also encourages, firms to effectively use hedging instruments against exchange rate exposure.

By presenting robust evidence on economic exchange rate exposure for domestic and multinational firms as well as the differential effects of positive and negative exchange rate changes on the market value of both types of firms, we have attempted to contribute to the scarce literature on foreign exchange rate exposure for firms operating in emerging and developing countries such as Pakistan. This analysis could be extended by examining the economic exchange rate exposure of other types of firms, such as exporting versus nonexporting firms, and small versus large firms. 


\section{References}

Adler, M., \& Dumas, B. (1980). The exposure of long-term foreign currency bonds. Journal of Financial and Quantitative Analysis, 15(4), 973-994.

Afza, T., \& Alam, A. (2011). Corporate derivatives and foreign exchange risk management: A case study of non-financial firms of Pakistan. Journal of Risk Finance, 12(5), 409-420.

Aggarwal, R., \& Harper, J. T. (2010). Foreign exchange exposure of 'domestic' corporations. Journal of International Money and Finance, 29(8), 1619-1636.

Allayannis, G. (1996). Exchange rate exposure revisited (Working Paper No. 97-06). Charlottesville, VA: University of Virginia.

Allayannis, G., Ihrig, J., \& Weston, J. (2001). Exchange-rate hedging: Financial versus operational strategies. American Economic Review, 91(2), 391-395.

Allayannis, G., \& Weston, J. (2001). The use of foreign currency derivatives and firm market value. Review of Financial Studies, 14(1), 243-276.

Al-Shboul, M., \& Anwar, S. (2014). Foreign exchange rate exposure: Evidence from Canada. Review of Financial Economics, 23(1), 18-29.

Alssayah, A., \& Krishnamurti, C. (2013). Theoretical framework of foreign exchange exposure, competition and the market value of domestic corporations. International Journal of Economics and Finance, 5(2), 1-44.

Aydemir, O., \& Demirhan, E. (2009). The relationship between stock prices and exchange rates: Evidence from Turkey. International Research Journal of Finance and Economics, 23, 207-215.

Barton, T. L., Shenkir, W. G., \& Walker, P. L. (2002). Making enterprise risk management pay off: How leading companies implement risk management. Upper Saddle River, NJ: Prentice Hall.

Bartov, E., \& Bodnar, G. M. (1994). Firm valuation, earnings expectations, and the exchange-rate exposure effect. Journal of Finance, 49(5), 1755-1785. 
Bartram, S. M. (2008). What lies beneath: Foreign exchange rate exposure, hedging and cash flows. Journal of Banking and Finance, 32(8), 15081521.

Baum, C. F., Caglayan, M., \& Barkoulas, J. T. (2001). Exchange rate uncertainty and firm profitability. Journal of Macroeconomics, 23(4), 565-576.

Bhuiya, M. I., Ahmed, E., \& Haque, M. E. (2015). Corporate international diversification, exchange rate exposure, and firm value: An analysis on United Kingdom multinationals. International Journal of Economics, Commerce and Management, 3(3), 1-22.

Bodnar, G. M., \& Wong, M. H. F. (1999). Estimating exchange rate exposure: Some 'weighty' issues. Unpublished manuscript, University of Pennsylvania, Philadelphia, PA.

Caporale, G. M., Pittis, N., \& Spagnolo, N. (2002). Testing for causality-invariance: An application to the East Asian markets. International Journal of Finance and Economics, 7(3), 235-245.

Carter, D. A., Rogers, D. A., \& Simkins, B. J. (2006). Hedging and value in the US airline industry. Journal of Applied Corporate Finance, 18(4), $21-33$.

Choi, J. J., \& Prasad, A. M. (1995). Exchange risk sensitivity and its determinants: A firm and industry analysis of US multinationals. Financial Management, 24(3), 77-88.

de Jong, A., Ligterink, J., \& Macrae, V. (2006). A firm-specific analysis of the exchange-rate exposure of Dutch firms. Journal of International Financial Management and Accounting, 17(1), 1-28.

Doidge, C., Griffin, J., \& Williamson, R. (2000). An international comparison of exchange rate exposure. Unpublished manuscript, Ohio State University, Columbus, $\mathrm{OH}$.

Dominguez, K. M., \& Tesar, L. L. (2006). Exchange rate exposure. Journal of International Economics, 68(1), 188-218.

Doukas, J., Hall, P. H., \& Lang, L. H. (1999). The pricing of currency risk in Japan. Journal of Banking and Finance, 23(1), 1-20. 
Doukas, J., Hall, P. H., \& Lang, L. H. (2003). Exchange rate exposure at the firm and industry level. Financial Markets, Institutions and Instruments, 12(5), 291-346.

Dumas, B. (1978). The theory of the trading firm revisited. Journal of Finance, 33(3), 1019-1030.

Faff, R. W., \& Marshall, A. (2005). International evidence on the determinants of foreign exchange rate exposure of multinational corporations. Journal of International Business Studies, 36(5), 539-558.

Fidora, M., Fratzscher, M., \& Thimann, C. (2007). Home bias in global bond and equity markets: The role of real exchange rate volatility. Journal of International Money and Finance, 26(4), 631-655.

Flota, C. (2014). The impact of exchange rate movements on firm value in emerging markets: The case of Mexico. American Journal of Economics, 4(2A), 51-72.

Froot, K. A., Scharfstein, D. S., \& Stein, J. C. (1993). Risk management: Coordinating corporate investment and financing policies. Journal of Finance, 48(5), 1629-1658.

Granger, C. W. J., Huang, B.-N., \& Yang, C.-W. (2000). A bivariate causality between stock prices and exchange rates: Evidence from recent Asian flu. Quarterly Review of Economics and Finance, 40(3), 337-354.

He, J., \& Ng, L. K. (1998). The foreign exchange exposure of Japanese multinational corporations. Journal of Finance, 53(2), 733-753.

Hodder, J. E. (1982). Exposure to exchange-rate movements. Journal of International Economics, 13(3-4), 375-386.

Jeddi, M. M. (2001). Foreign exchange risk exposure of Canadian domestic, exporting and multinational firms: Market and industry effects on bilateral and multilateral exchange rates. Unpublished manuscript, Concordia University, Montreal.

Jongen, R., Muller, A., \& Verschoor, W. (2012). Using survey data to resolve the exchange risk exposure puzzle: Evidence from US multinational firms. Journal of International Money and Finance, 31(2), 148-169. 
Jorion, P. (1990). The exchange-rate exposure of US multinationals. Journal of Business, 63(3), 331-345.

Jorion, P. (1991). The pricing of exchange rate risk in the stock market. Journal of Financial and Quantitative Analysis, 26(3), 363-376.

J.P. Morgan. (2017). Strategies for a strong US dollar environment: The other side of the coin. New York City: Author.

Kemal, M. A. (2005). Exchange rate instability and trade: The case of Pakistan (Research Report No. 186). Islamabad: Pakistan Institute of Development Economics.

Khan, M. A., \& Qayyum, A. (2007). Exchange rate determination in Pakistan: Evidence based on purchasing power parity theory. Pakistan Economic and Social Review, 45(2), 181-202.

Kiymaz, H. (2003). Estimation of foreign exchange exposure: An emerging market application. Journal of Multinational Financial Management, 13(1), 71-84.

Kutty, G. (2010). The relationship between exchange rates and stock prices: The case of Mexico. North American Journal of Finance and Banking Research, 4(4), 1-12.

Lam, J. (2003). Enterprise risk management: From incentives to controls. Hoboken, NJ: Wiley.

Leland, H. E. (1998). Agency costs, risk management, and capital structure. Journal of Finance, 53(4), 1213-1243.

Levi, M. D. (1994). Exchange rates and the valuation of firms. In Y. Amihud \& R. Levich (eds.), Exchange rates and corporate performance (pp. 3248). Washington, DC: Beard Books.

Madura, J. (1989). International financial management (2nd ed.). St Paul, MN: West Publishing Company.

Marston, R. C. (2001). The effects of industry structure on economic exposure. Journal of International Money and Finance, 20(2), 149-164. 
Miller, K. D., \& Reuer, J. J. (1998). Firm strategy and economic exposure to foreign exchange rate movements. Journal of International Business Studies, 29(3), 493-514.

Muhammad, N., \& Rasheed, A. (2002). Stock prices and exchange rates: Are they related? Evidence from South Asian countries. Pakistan Development Review, 41(4), 535-550.

Nydahl, S. (1999). Exchange rate exposure, foreign involvement and currency hedging of firms: Some Swedish evidence. European Financial Management, 5(2), 241-257.

Pan, M.-S., Fok, R. C.-W., \& Liu, Y. A. (2007). Dynamic linkages between exchange rates and stock prices: Evidence from East Asian markets. International Review of Economics and Finance, 16(4), 503-520.

Pan, Y., \& Tang, C. (2012, September). Study on the relationship between exchange rate fluctuation and stock return: Evidence from listed companies in China. Paper presented at the International Conference on Management Science and Engineering, Dallas, TX.

Papaioannou, M. (2001). Volatility and misalignments of EMS and other currencies during 1974-1998. In J. J. Choi \& J. M. Wrase (eds.), European Monetary Union and capital markets (pp. 51-96). Amsterdam: Elsevier.

Papaioannou, M. (2006). Exchange rate risk measurement and management: Issues and approaches for firms (Working Paper No. 06/255). Washington, DC: International Monetary Fund.

Pritamani, M. D., Shome, D. K., \& Singal, V. (2004). Foreign exchange exposure of exporting and importing firms. Journal of Banking and Finance, 28(7), 1697-1710.

Rashid, A. (2010). The economic exchange rate exposure: Evidence for a small open economy. IUP Journal of Monetary Economics, 8(4), 46-58.

Rashid, A. (2013). The response of inflation to its determinants: Does it differ at short and long horizons? International Journal of Economics and Business Research, 6(2), 229-242. 
Rashid, A., \& Khalid, A. (2017). The impact of exchange-rate uncertainty on foreign portfolio investment in Pakistan. NUML International Journal of Business and Management, 12(2), 88-102.

Rashid, A., \& Waqar, S. M. (2017). Exchange rate fluctuations, firm size, and export behavior: An empirical investigation. Small Business Economics, 49(3), 609-625.

Shapiro, A. C. (1996). Multinational financial management (5th ed.). Hoboken, NJ: Wiley.

Smith, C. W., \& Stulz, R. M. (1985). The determinants of firms' hedging policies. Journal of Financial and Quantitative Analysis, 20(4), 391-405.

Solnik, B. (1987). Using financial prices to test exchange rate models: A note. Journal of Finance, 42(1), 141-149.

Stavárek, D. (2005). Stock prices and exchange rates in the EU and the USA: Evidence of their mutual interactions. Czech Journal of Economics and Finance, 55, 141-161. 